\title{
The combination of tile vaults with reinforcement and concrete
}

\section{David López López, Tom Van Mele \& Philippe Block}

To cite this article: David López López, Tom Van Mele \& Philippe Block (2018): The combination of tile vaults with reinforcement and concrete, International Journal of Architectural Heritage, DOI: $10.1080 / 15583058.2018 .1476606$

To link to this article: https://doi.org/10.1080/15583058.2018.1476606

册 Published online: 06 Jun 2018.

Submit your article to this journal $₫$

View related articles $\nearrow$

View Crossmark data $\nearrow$ 


\title{
The combination of tile vaults with reinforcement and concrete
}

\author{
David López López 주, Tom Van Mele, and Philippe Block
}

ETH Zurich, Institute of Technology in Architecture, Block Research Group, Zurich, Switzerland

\begin{abstract}
Tile vaults are unreinforced masonry structures made of thin bricks (tiles) and fast-setting mortar that can be constructed needing only formwork along their boundaries, making them inherently economic. Their slenderness and finishing make them also efficient and expressive.

These qualities of tile vaulting can be enhanced by combining it with concrete and/or reinforcement. A top layer of concrete reduces time and labour, whereas reinforcement can reduce the thickness, allows the construction in seismic areas and opens the formal possibilities of tile-vaulted construction beyond compression only. A few architects and engineers, such as Guastavino, Gaudí, Le Corbusier, and Torroja, among others, envisioned some of these qualities and used these combinations in their buildings.

This article reviews the unique examples of tile vaulting combined with concrete and/or reinforcement in the past, showing their successful results and giving an overview of how their authors faced the structural analysis and design.
\end{abstract}

ARTICLE HISTORY

Received 14 February 2018

Accepted 11 May 2018

\section{KEYWORDS}

Catalan; composite;

concrete; shells; formwork; Guastavino; reinforcement; tile vault; timbrel

\section{Introduction}

Tile vaults (often also referred to as thin-tile, timbrel, Catalan, or Guastavino vaults) are masonry structures made with thin bricks (tiles) and a fast-setting mortar. The bricks are placed flat, building up two, three, or more layers. Traditionally, tiles are used because of their lightness, which is a necessary condition to build the first layer "in space", without supporting falsework (Figure 1). The first layer is achieved through the quick adhesion of binders such as gypsum or fast-setting cement. The bricks stick within seconds to the edge walls, or the already finished arches or stable sections, taking away the necessity of centering (Huerta 2001). Using this first layer as a permanent formwork, the second and subsequent layers can be set with lime or Portland cement mortar.

The construction "in space" (without the need for formwork), thanks to the use of fast-setting binders and thin (light) ceramic pieces, is thus one of the most relevant characteristics of this technique, and what makes it inherently economical. Therefore, it should be distinguished from other techniques that might have a similar final result, but with a different construction process, such as, for example, the extraordinary reinforced-brick architectural pieces by the Uruguayan engineer Eladio Dieste. The use of a formwork allows
Dieste to use thicker bricks and to place reinforcement in the joints. His buildings were also economically competitive due to the use of a single formwork for a shape that is repeated along the length of the building. The work by the Colombian engineer Guillermo González Zuleta and the Spanish engineer Ildefonso Sánchez del Rio using similar techniques to build reinforced brick shells with a formwork is also remarkable (López López, Van Mele, and Block 2016a). However, none of these examples are in the scope of this article.

Other masonry construction techniques, such as the "Nubian vaults" or the "Mexican vaults", also avoid the use of formwork (Martínez Fernández 2011; Wendland 2007). However, their outcome and construction process (not using tiles, not relying on a fast-setting binder and not placing the bricks flat) are sufficiently different not to be included in this article's review.

This article focuses on the review of relevant examples of constructions built with the technique of tile vaulting in combination with reinforcement or with an additional layer of mortar or concrete. These combinations feature several advantages and have given successful results in the past. These advantages add a new range of possibilities to a technique, which is experiencing a renaissance since the beginning of the 21 st century thanks to its economy, efficiency, sustainability, and expressiveness (López

CONTACT David López López lopez@arch.ethz.ch ETH Zurich, Institute of Technology in Architecture, Block Research Group, Stefano-Franscini-Platz 1, HIB E45, 8093 Zurich, Switzerland.

Color versions of one or more of the figures in the article can be found online at www.tandfonline.com/uarc.

(c) 2018 Taylor \& Francis 


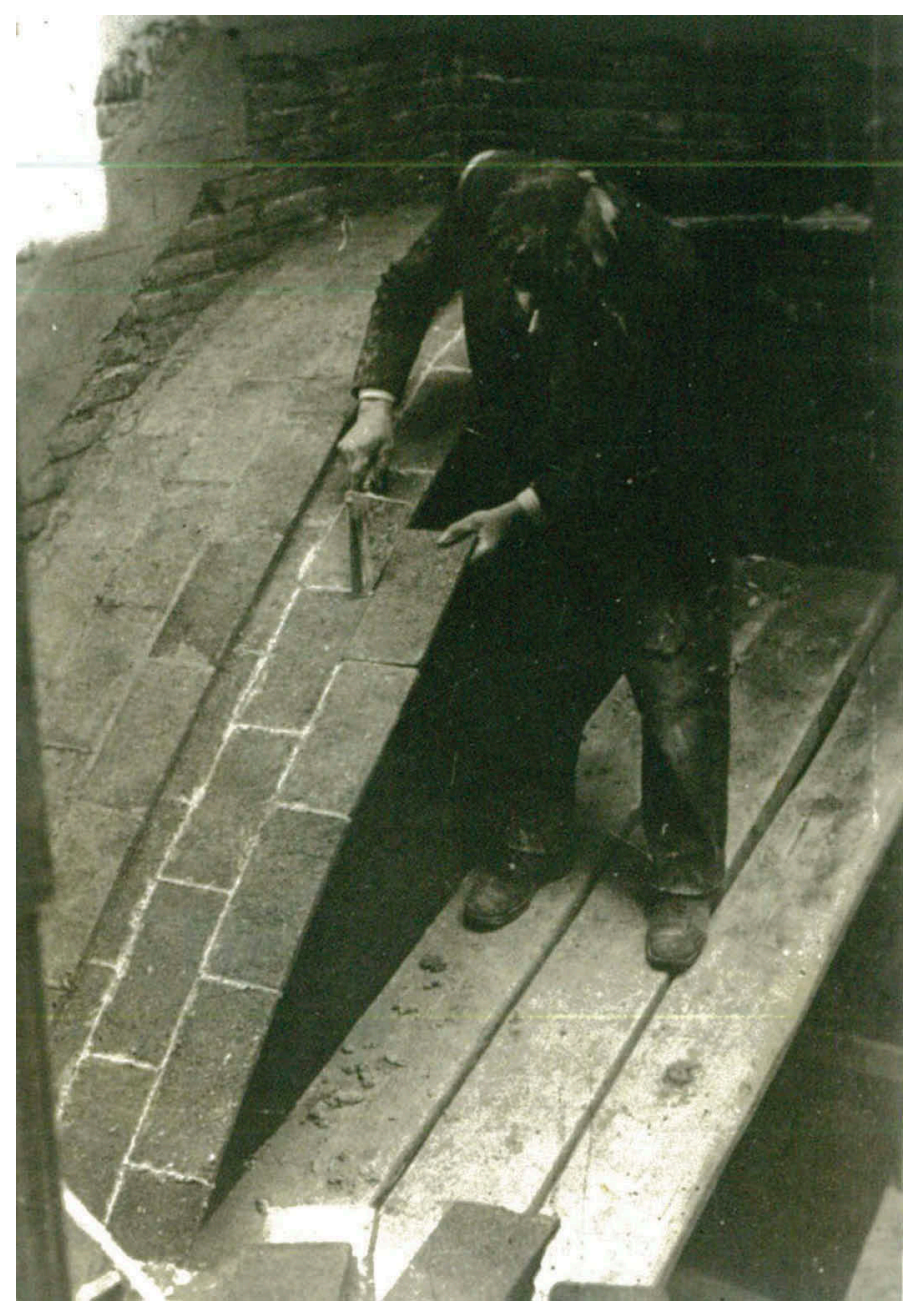

Figure 1. Construction of a stair tile vault (Truñó A. ca. 1951a).

López, Domènech, and Palumbo 2014; López López, Van Mele, and Block 2016b).

Each of the next three sections of this article presents a different combination of tile vault with reinforcement and/or concrete. Section 2 presents tile vaults as formwork for unreinforced concrete, Section 3 is devoted to reinforced tile vaults, and Section 4 is dedicated to the composite system of tile vaults and reinforced concrete. Architectural pieces featuring these techniques are also described in each section. Subsections present the way the architects and engineers of those works faced the structural analysis and design.

\section{Tile vault as formwork for unreinforced concrete}

This system consists of a tile vault with one, two, or more layers of bricks, and a top layer of concrete (or mortar). Once the tile vault is built "in space", it is used as formwork for the concrete.
The construction of concrete shells requires formwork with rigid shuttering onto which concrete can be poured and allowed to harden. These formworks are typically complex and unique, and most times not reused. Furthermore, their construction is labour and material intensive, and often even requires a separate foundation. Therefore, formworks for concrete shells are expensive and wasteful. Tile vaults can be used as permanent formwork for concrete shells to reduce construction waste and cost (of the formwork itself but also of the foundation to support the falsework), and thereby provide an interesting solution for the efficient construction of vaulted structures. Concrete would be applied onto a tile-vaulted formwork, afterward forming a composite structure. On the one hand, as compared to a typical tile vault with multiple (more than two) layers, the addition of a top layer of concrete to, for example, a two-layered tile vault, reduces time and labor because of the easier applicability of the concrete in comparison with the placing of the bricks. A higher weight for the same thickness should be expected 
though, due to the concrete's higher specific weight. On the other hand, as compared to a typical concrete vault, this system reduces costs by allowing the construction without a formwork. Besides, it provides an exceptional finishing to the intrados. As drawback, the new composite structure presents a more complex structural behaviour, in which the bonding between the two materials plays an important role.

Although current studies place the origin of tile vaulting in the South of Spain in the $11^{\text {th }}$ century (Fortea 2009), some authors identified its origin in a similar technique in Roman constructions (Bergós 1965). This Roman technique, explained by Auguste Choisy in his book L'art de bâtir chez les Romains (Choisy 1873), consisted of a first layer made of big, square ceramic pieces (with an edge size around $60 \mathrm{~cm}$ and a thickness of $4-5 \mathrm{~cm}$ ), placed with gypsum or fast-setting cement, and a second layer of smaller bricks (sometimes only placed over the joints of the first layer). The building process required centring consisting of wooden planks on which the big ceramic pieces rested (Figure 2, left). This ceramic system was used as a permanent formwork to pour their special Roman "concrete." In order to make a good connection between the ceramic vault and the concrete, they used bricks placed in perpendicular direction, effectively connecting the ceramic and concrete parts of the structure. In his book Histoire de l'Architecture, Choisy (1899) also describes the Roman technique being built "dans le vide" ("in space") (Figure 2, right).
The first description of the tile vaulting technique in a treatise was not in Choisy's books, but in Arte y Uso de Arquitectura ("Art and Use of Architecture") by Fray Lorenzo de San Nicolás (1633) (González 2004). Although not mentioning concrete (or mortar) or a composite structure similar to the one presented in this section, Fray Lorenzo described the common addition of filling material over the tile vault from its supports until one third of its length. The importance of having spandrel walls or filling material on such a slender vault was also pointed out by Choisy (1873) (Figure 3, left) and very well-known traditionally and by the Guastavinos, whose "rib and dome system" did include the option of having concrete as filling material to both stiffen the vault and reach the flat level of the floor (Figure 3, right).

In 1891, Rafael Guastavino Moreno (Guastavino Sr., 1842-1908) registered a U.S. patent of a tile barrel vault as a permanent formwork for either more layers of bricks or concrete (Figure 4). For the construction of his "invention," he used "a small light wooden frame constantly shifted during the prosecution of the work" instead of the common "cumbersome and heavy temporary wooden centers" (Guastavino Moreno 1891; Waite and Gioia 1999).

One year later, in 1892, his son Rafael Guastavino Expósito (Guastavino Jr., 1873-1950) presented a new patent with two main additions to his father's: metallic anchors to ensure the bond between the two materials
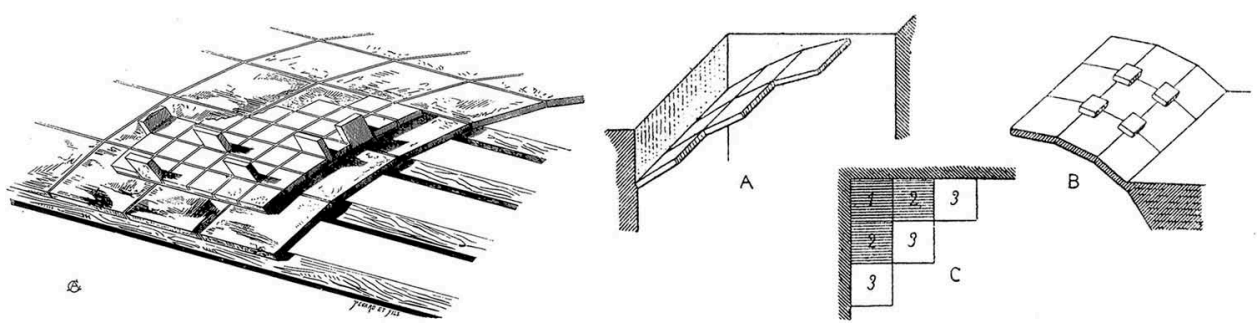

Figure 2. Roman technique to build vaults. (Left) with wooden planks as centring (Choisy 1873); (right) "in space" (Choisy 1899).
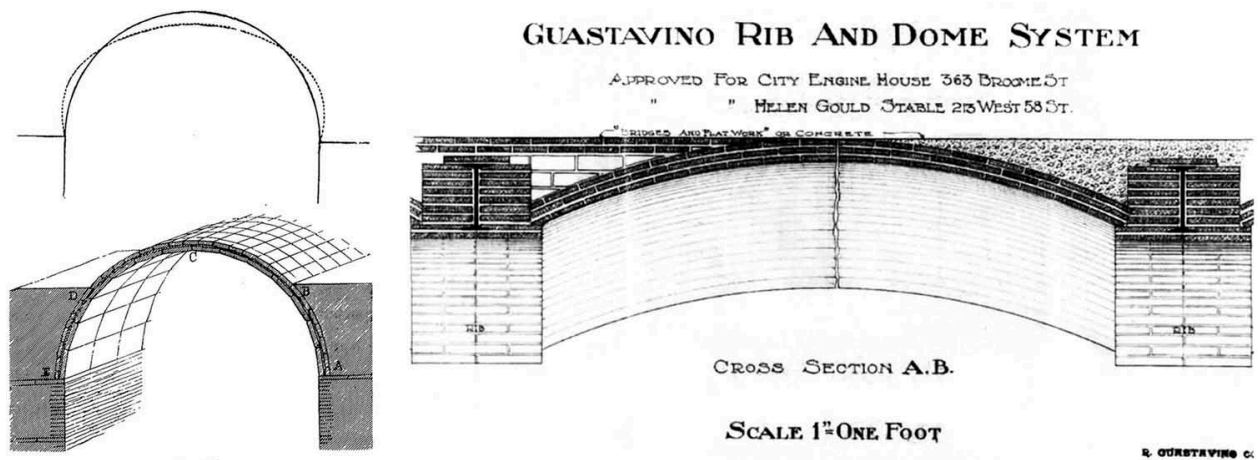

Figure 3. Tile vaults with filling material. (Left) descriptive drawings by Choisy (1873); (right) Guastavino Rib and Dome System. 

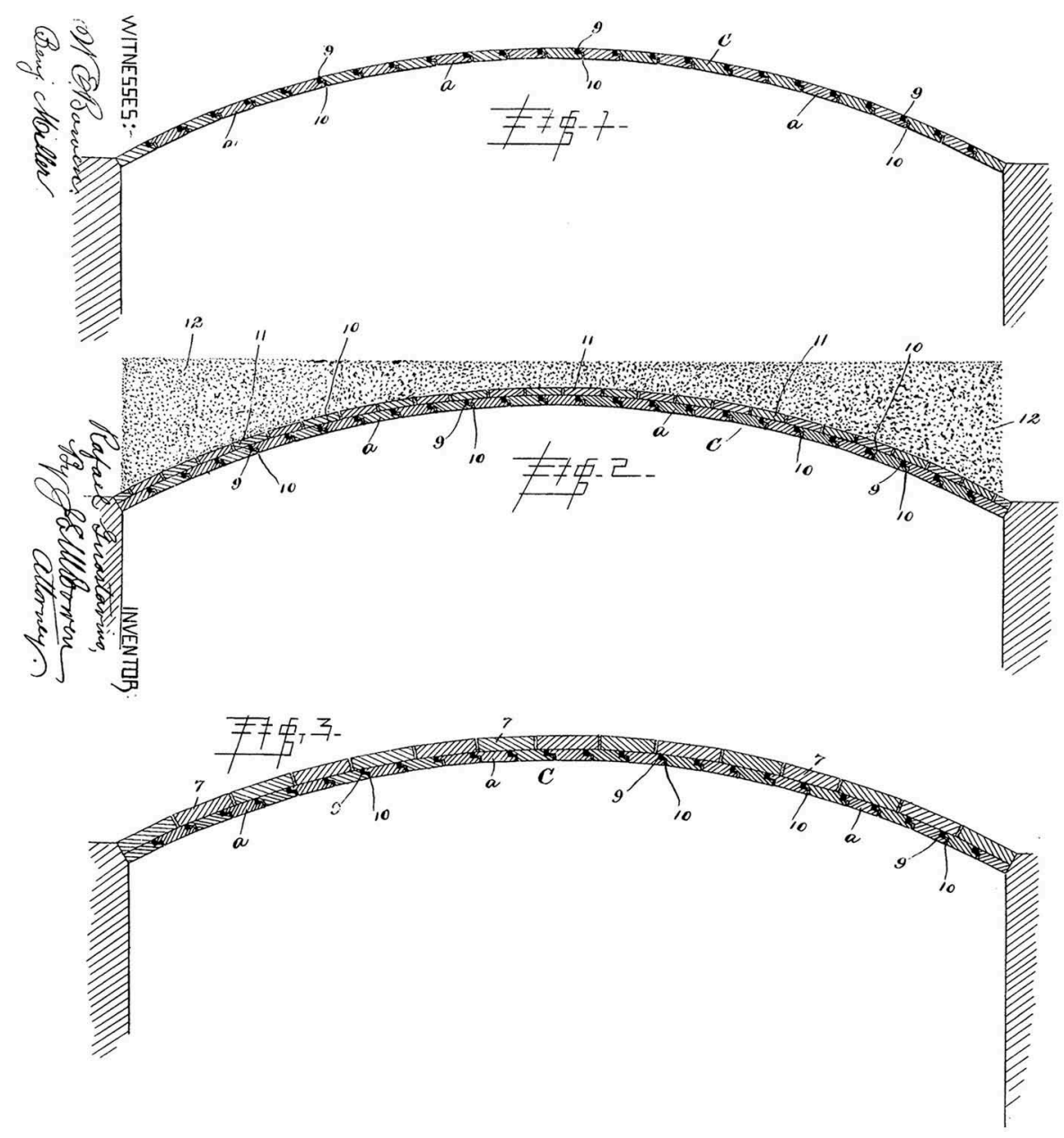

Figure 4. Guastavino's drawings for his patent No. 464,562 (1891).

and "a series of ribs made of tiles [...] serving to reinforce the thin foundation tile arch, and thus permit the workmen to walk over the structure with absolute safety when laying the concrete or cement" (Figure 5, left) (Guastavino Expósito 1892; Waite and Gioia 1999). The drawings of this patent from 1892 and the concepts of "ribs" on the tile vault as stiffeners present clear similarities with the ones featured in the Roman constructions shown in Choisy's Histoire de l'Architecture (1899) (Figure 5, right).

Shortly after the Guastavinos' emigration from Catalonia to the U.S. in 1881, Catalan Modernism would raise the expressiveness of the tile vaulting technique, with architects such as Antoni Gaudí, Lluís
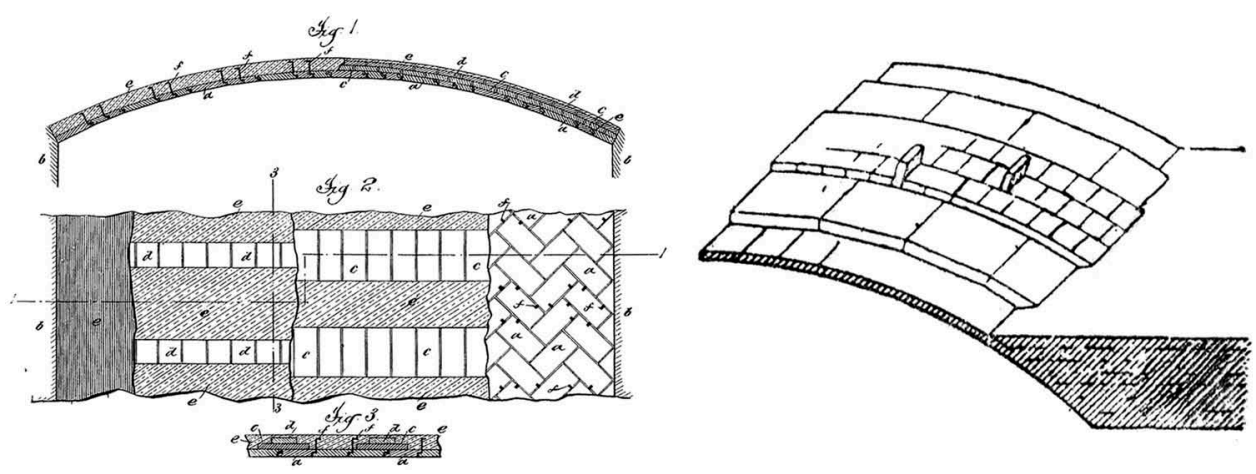

Figure 5. Tile vaults as formwork for unreinforced concrete. (Left) Guastavino Jr.'s drawings for his patent No. 468,871 (1892); (right) Choisy's drawing to describe the Roman technique (Choisy 1899). 
Muncunill, or Lluís Domènech i Muntaner. The genius of Antoni Gaudí (1852-1926) produced a striking example of the combination of tile vaults with concrete for the vaults of the porch of the Colonia Güell's church (1908-1914) (González 2000; González and Casals 2002) (Figure 6, left). According to González and Casals (2002), these vaults would be the first ones in the history of architecture with the shape of a hyperbolic paraboloid. The ruled surface would have allowed the construction of a single-layered tile vault using a falsework made of straight wooden planks. Concrete was then poured on the tile-vaulted integrated formwork. Once the structure set and the falsework was removed, an additional layer of mortar with little pieces of tiles was added from underneath to smoothen the faceted surface. A last decorative layer made of triangular tile remnants was also added to the intrados (Figure 6, right) (González and Casals 2002).

The impressive work of the Catalan architect was (and still is) an inspiration for many architects. The famous Le Corbusier (1887-1965) got impressed with Gaudí's work in 1928 (Gulli 2001). He had been invited to a conference in Barcelona by José Luis Sert. In his notes and sketches, Le Corbusier drew the Schools of Sagrada Familia and made references to Gaudí and the tile vaulting technique. Over 20 years later, in 1950, he was again with Sert in Bogotá, visiting Francisco Pizano 's house, in which a tile vaulted stair called his attention. He sketched construction details of the stairs and wrote notes about the technique. Inspired by these works, he would use tile vaults as formwork for unreinforced concrete in two of his built projects, the Jaoul Houses and Sarabhai Villa.

The existence of tile vaults in Colombia is known by many academics mainly thanks to the research made about Le Corbusier's inspiration to use tile vaults in the Jaoul Houses (Gulli 2001; Maniaque 2005), especially through his sketches of Francisco Pizano's house, which was built with the help of the Catalan engineer Fernando Murtra and workers also coming from Catalonia (Rodríguez 2008). Pizano was at that time one of the young architects working with Le Corbusier on the master plan of the city, on which Sert was also working. According to Pizano (Rodríguez 2008), his house included a three-layered, tile-vaulted stair and a "tile vault" made with bricks with probable measurements of $24 \times 12 \times 6 \mathrm{~cm}$. Le Corbusier's drawings of a three-layered tile vault were sketches for his unbuilt project "Maison des Péons" in Chandigarh (Gulli 2001). Some drawings from 1951 for the same project include a mesh of rebars in between the joints of the second layer of bricks (Gulli 2001). That would have been the first project by Le Corbusier using reinforced brick. Not a novelty at that time though, as Antoni Bonet, who worked in Le Corbusier's office from 1937-1939, had already built such a structure, together with Eladio Dieste in the Berlinguieri House (19461947), which is considered the first vault in reinforced brick (López López, Van Mele, and Block 2016a; Marín and Trallero 2005; Tomlow 2001). The novelty of Le Corbusier's system would have been in the use of a tile vault as permanent formwork for the reinforced brick structure. Another way to understand this scheme would be as a reinforced tile vault, not with the reinforcement between the layers (examples of this are shown in Section 3), but in between the joints of the second layer of bricks.

Inspired by, among others, Le Corbusier and Bonet, Latin-American architects, used vaults and the tile-vaulted technique in their projects as an effective solution regarding functionality and economy (García, González, and Losada 2012). The Argentinian architect Eduardo Sacriste (1905-1999) is co-author of the book Viviendas con Bóvedas ("Dwellings with vaults") (Sacriste, Kechichian, and Mackintosh 1977). This book presents a compilation of housing projects in Argentina featuring masonry vaults with many variations, including the tile vault as formwork for unreinforced concrete. Special attention is given to the technique of tile vaulting, reproducing a whole chapter about it by Félix Cardellach in his book Filosofía de las estructuras (Cardellach 1910) and using Choisy's drawings to explain the above-mentioned Roman technique as the origin of
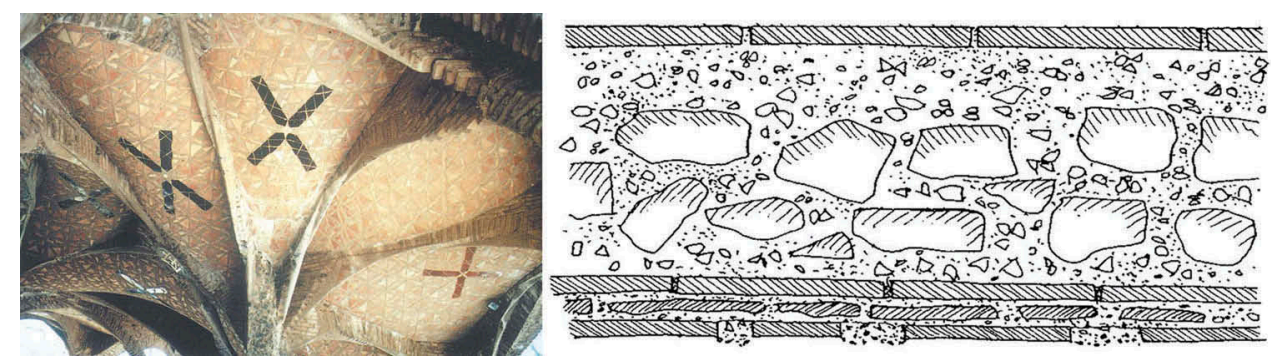

Figure 6. Porch of the Colonia Güell's church. (Left) view of the vaults; (right) cross-section of the vaults. 
the current tile vault. In the wide variety of this compilation of vaults, some pictures and drawings show the construction of vaults with falsework using as first layer the Roman-like, large and thin ceramic elements joined with gypsum (Figure 7, left) and some include a layer of concrete on top (Figure 7, right).

\section{Structural analysis and design}

Although the presented architects did not accurately explain the way they calculated or even understood this composite structure, this can be inferred from the way they calculated and understood tile-vaulted structures.

Guastavino Sr.'s theory on the structural behaviour of tile vaults was published first in 1892 and again, slightly modified, in 1893 (Huerta 2006b). He called it Essay on the Theory and History of Cohesive Construction, Applied Especially to the Timbrel Vault (Guastavino Moreno 1893). His theory presents some contradictions, especially when compared to his practice (Huerta 2001). Influenced by the structural ideas of elasticity of the time, he spoke about tile vaults as continuous, homogeneous, rigid solids, as a consequence of their cohesive nature. However, due to the difficulty to perform elastic calculations, he used equilibrium equations to calculate the horizontal thrust and the required thickness and then did some resistance verifications according to his own experimental results and the coefficients he considered appropriate (Huerta 2001). Guastavino Sr. was aware of his limitations, and left the duty to develop a more scientific and accurate theory to the academics (Guastavino Moreno 1893). His designs were, in fact, mostly guided by his vast experience and his extraordinary intuition (Ochsendorf 2010).

Guastavino Sr. considered concrete also a cohesive material. For him, the joints in the traditional masonry arches were the weak points and one of the main differences with the cohesive tile vaults, which do not have vertical continuous joints thanks to their layers. An arch made of concrete does not have any joint, however, Guastavino Sr. identified the need for formwork, the eventual unequal curing, its high price and the need to build arches in one lift (only possible for short-span structures) as main problems related to concrete arch construction (Guastavino Moreno 1893; Huerta 2001). The text of his patent from 1891 explains the two above-mentioned alternatives of a singlelayered vault used as formwork (Figure 3). Between the option of pouring concrete (Figure 3, middle) and adding more layers of bricks (Figure 3 , bottom), he points out that the one with only bricks is preferred. Although no reason for that statement is given in this case, looking at his drawings, the slenderness and material efficiency of the brick option compared to the concrete one is quite revealing. For the tile-vaulted floor arch, he only used an additional layer of "common bricks built over my [his] permanent center", which was enough to create a stable structure. For the option with concrete, and assuming the same span, the arch was "completed over the center by a course of common tiles [...] and a layer of concrete" (Guastavino Moreno 1891). He drew a second layer of tiles, thinner than the "common bricks," needed to resist the concrete's weight while curing and the live loads from the construction process, namely workers walking over the construction and the weight of tools and materials. For the same construction process, with slightly thicker bricks, a great mass of concrete can be saved. It should be pointed out that the use of concrete showed in that drawing is far from being optimised, which demonstrates his little interest in this option. In terms of structural calculations and design, the finished composite structure probably was treated as a homogeneous, cohesive arch.

In the case of Guastavino Jr.'s patent from 1892, the use of concrete seems to be much more meditated (Figure 4, left). It is used only for the main structural
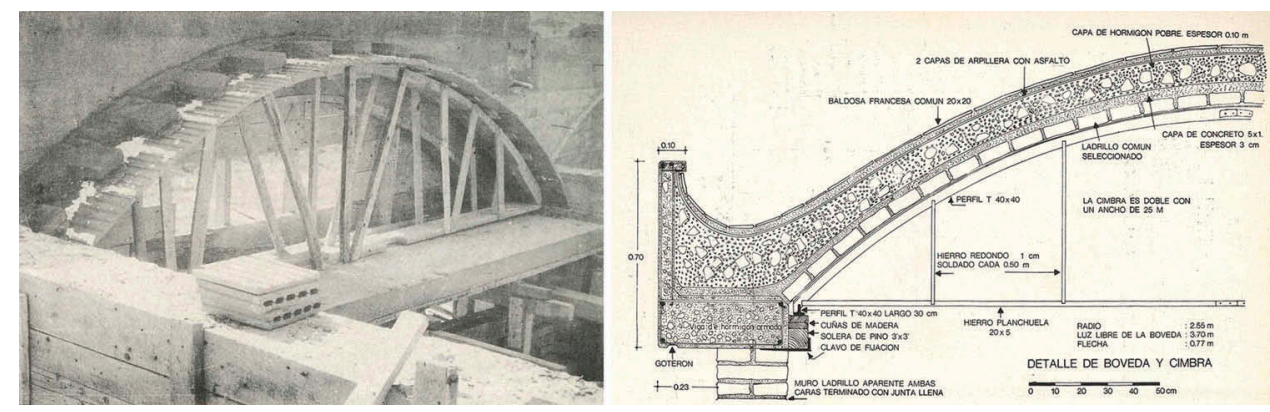

Figure 7. Vaults at the house Clérico Hermanos in El Galpón, Argentina (Architect Eduardo Sacriste). (Left) Construction of a vault; (right) detail of the vault and the centering (Sacriste, Kechichian, and Mackintosh 1977). 
element, the vault, and not as filling material to stiffen it and/or to achieve a flat surface, functions that can be more efficiently fulfilled by other materials or systems. Metallic anchors ensured a joint structural behaviour, which gave Guastavino Jr. an additional security to consider the system as cohesive when facing the structural analysis.

Although Guastavino Jr. used graphic statics for the design and analysis of many of his structures, it can be supposed that he learnt this method only in 1907, during the construction of St. Paul's Chapel in New York. For that project, the engineer in charge of the dome's structural analysis, Nelson Goodyear, used graphic statics to that end (Figure 8) and it was most likely from him that Guastavino Jr. learnt the method's fundamentals (Ochsendorf 2010). Although Guastavino Jr. was a self-taught person who studied art, architecture, and structures (Huerta 2001), in the early years of his career it was most probably his father's lessons which he applied for his calculations.

Gaudí's education in the Architecture School of Barcelona between 1873 and 1878 did include graphic statics. He did not use this method only for the assessment of already defined shapes, but he included it also in the design of his structures, introducing a novelty that allowed a form-finding process based on structural optimisation. To this end, he employed iterative graphic methods and hanging physical models (Huerta 2006a). However, in the specific case of the vaults at the porch of the Colonia Güell's church, their shape is not form-found, but a series of hyperbolic paraboloids (González and Casals 2002).

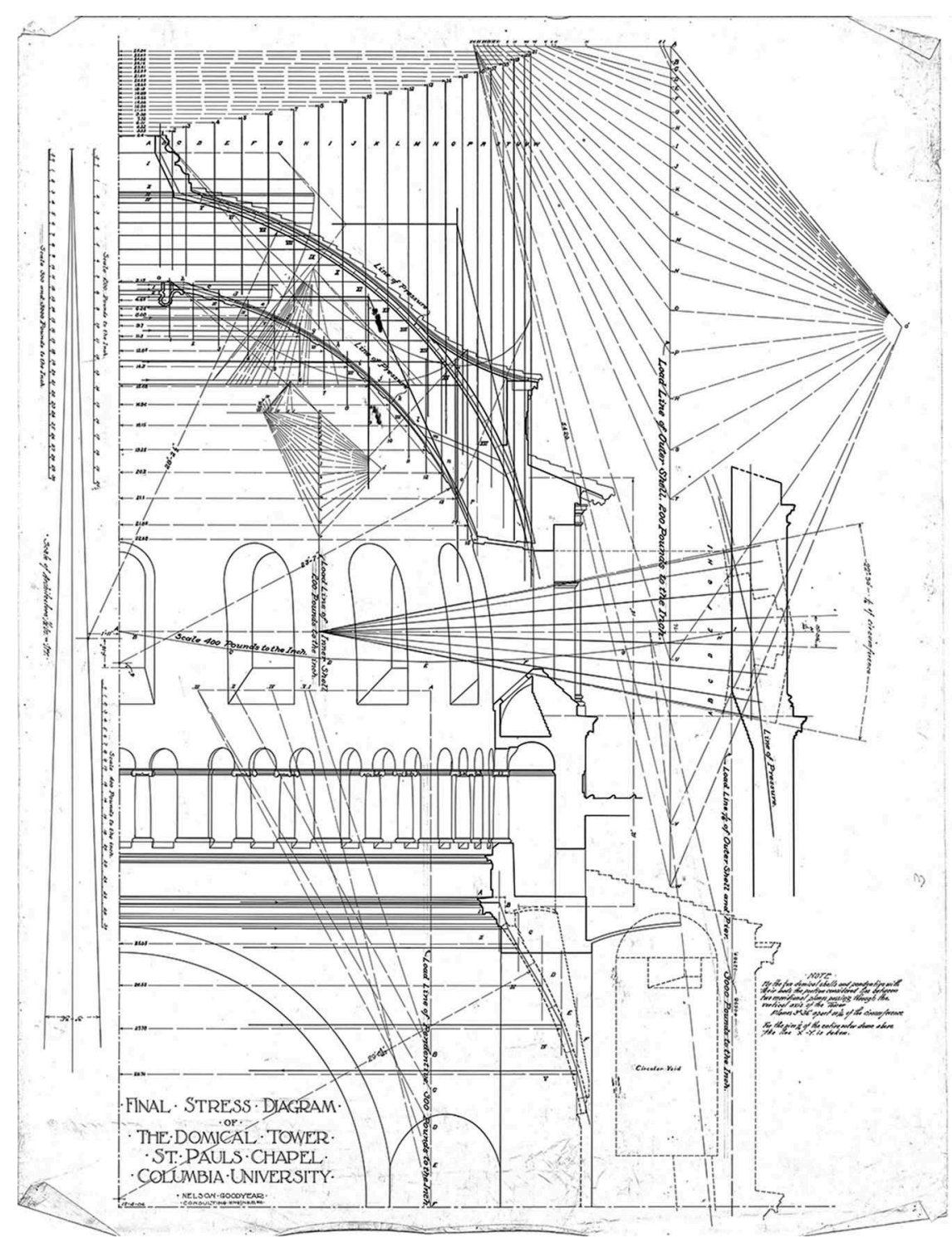

Figure 8. Engineer Nelson Goodyear's graphical analysis of St. Paul's Chapel dome, New York City (Guastavino Archive, Avery Library). 
Although this shape, ingeniously applied by Gaudí, might give the impression of non-compression-only vaults, the second family of curves creating the hyperbolic paraboloid will always have the desired arch action in one direction, allowing Gaudí to assess the structural performance of such structures using graphic statics and considering the thickness of the vault as the addition of the tile vault and the concrete.

While Gaudí and the Guastavinos were expert tile vault builders from places where this traditional technique was widely spread and its good structural performance was assumed as a fact (although not always well understood), Le Corbusier was not at all familiar with it. He used the tile vaults as a permanent formwork for his concrete vaults, having as main purpose the recovery of the expressive quality of the traditional technique. His notes are clear in the separation of the structure (concrete) and the formwork (the tile vault). This concept is also present in the way the Jaoul Houses are structurally analysed: applying the simple formulas from the elastic theory to the concrete, and disregarding the structural capacity of the masonry (Gulli 2001).

Although also not educated in Spain, Eduardo Sacriste's clear trust in Cardellach's theories about tile vaults leads the authors to believe that, if he did his own calculations, he must have applied the elastic theory including both tile vault and concrete in his calculations. Cardellach considered tile vaults "the definitive conclusion of the cohesive system" (Cardellach 1910) and believed in their capacity to resist bending moments and to create any kind of shape. The thrust line, therefore, did not need to lie within the thickness of the vault and their stability could be verified just as it is done with steel structures.

It is worth to highlight the difference in the formal complexity of the vaults built by the architects mentioned in this section. Whereas the Guastavinos and Gaudí needed laborious graphic statics drawings to either analyse or design their (sometimes) complex shells, Le Corbusier and Sacriste built short-span barrel vaults that required more simple calculations.

\section{Reinforced tile vault}

With the term "reinforced tile vault" the authors refer to tile vaults with reinforcement in between the layers, embedded in any of the intermediate joints of mortar. This reinforcement gives additional tensile and bending capacity allowing a reduction in the thickness of the vault and making it appropriate for eventual asymmetrical loading or seismic activity. This system would also allow the construction of non-compression-only structures. Whereas steel reinforcement bars can be placed easily on singly curved or ruled surfaces, complex shapes may demand a mesh/textile reinforcement, which, in addition, do not require the mandatory cover to prevent corrosion on the steel elements.

Once more, Gaudí and the Guastavinos were pioneers, in this case in the reinforcement of tile vaults. Although not used in an emblematic building, nor in a significant part of it, it is worth to briefly mention the metallic twisted straps that Gaudí used to reinforce some of the tile vaults in the Park Güell's entrance pavilions (1903-1905) (Aguado, Ribas, and Hosta 2002).

Guastavino Jr. filed an application of a patent featuring reinforced tile vaults in 1908 and used the system for the first time at the biggest tile vault ever built: the dome of St. John the Divine's Cathedral (1909) (Ochsendorf 2010). This U.S. patent, approved in 1910 , consists of a tile vault, dome or wall with metallic reinforcement in between its layers (Figure 9). These rods are "protected from moisture and the atmosphere, and are also protected from any direct heat which would cause them to expand more rapidly than the tiles from which the structure is constructed" (Guastavino Expósito 1910; Waite and Gioia 1999).

Gaudí and the Guastavinos influenced other architects who also used reinforced tile vaulting. Joan Bergós (1894-1974) was a friend and an admirer of Gaudí. With the intention to help with the polemic continuation of Gaudi's unfinished Temple of Sagrada Familia, he did a comprehensive theoretical and experimental research on the structural behavior of different kind of elements made of tile layers using the traditional Catalan technique, reinforced and unreinforced (Bergós 1965). He claimed that the new materials (hollow bricks and binders) had a much better behavior than the ones used by Gaudí and the resulting tile vaults would be constructively and mechanically superior. He did calculations and performed compression, shear (mortar adherence) and flexural tests on different kind of arches, walls, blocks, and cylindrical elements, with different number of layers, boundary conditions, loads, and reinforcement (Figure 10). The placement of the steel rebars varied: between layers and underneath or on top of the whole system. This research was published in the book Tabicados Huecos in 1965. However, the use of reinforced tile vaults was not new to Bergós at that time. After the Spanish Civil War, in 1941, he received the commission for the construction of the dome of the unfinished church Inmaculado Corazón de María in Barcelona, built by the architect Joan Martorell between 1904 and 1913. For this 13-m- 

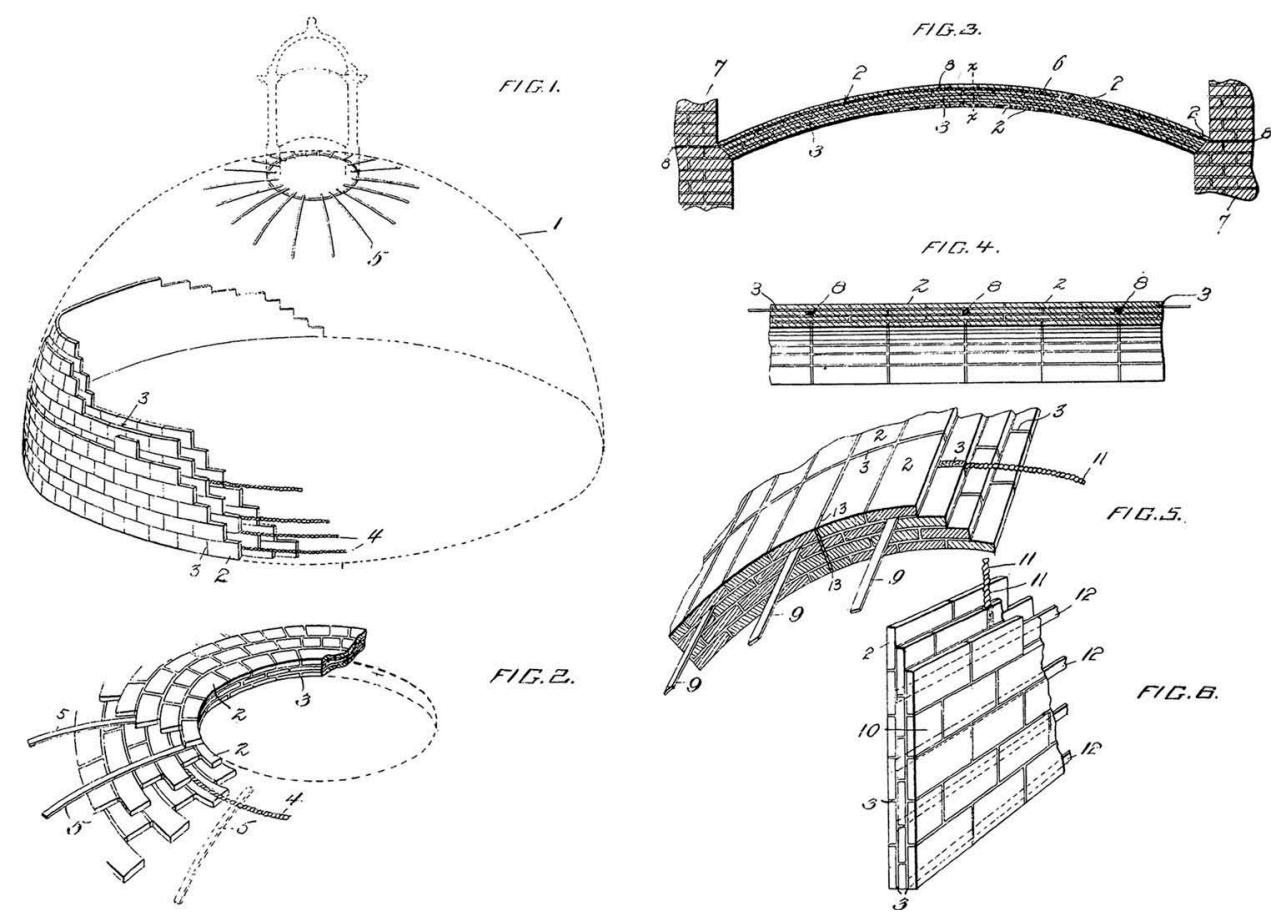

Figure 9. Guastavino Jr.'s drawings for his patent No. 947,177 (1910).
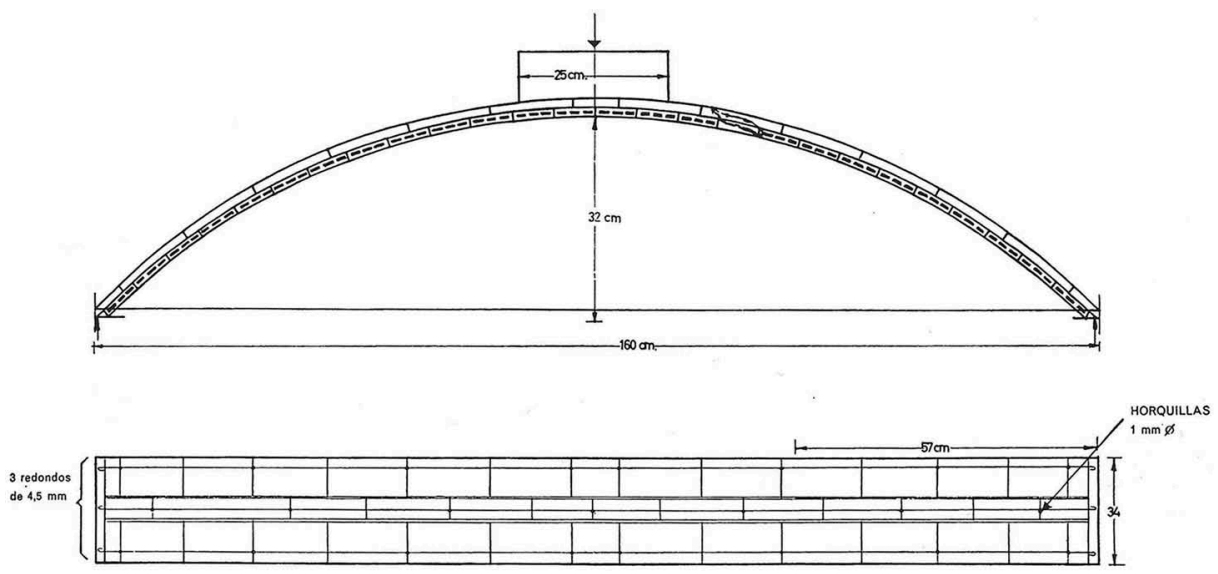

Figure 10. Load test setup of a reinforced tile vault (Bergós 1965).

span dome, Bergós used a 10-cm-thick, three-layered tile vault with steel reinforcement embedded in one of the mortar joints between layers (Bergós 1965).

It will always remain unknown if Gaudí would have approved all the current construction systems and materials of the Sagrada Familia. The current builders make efforts to spread the justifications for the use of reinforced concrete, based mainly on safeness and on the previous use of reinforced concrete by Gaudí (Buxadé and Margarit 2001; Espel et al. 2009; Gómez 2001). A detailed exposition of arguments, pros and cons, about the continuation of the works and the use of reinforced concrete in the Temple has been exposed in González and Casals
(2002, 167-170), with the conclusion that Gaudí would have approved both of them nowadays. Be that as it may, reinforced tile vaults and tile vaults as permanent formwork for reinforced concrete are being and have been built in the Temple. Taking advantage of the geometry of the vaults consisting of ruled surfaces, they are reinforced with straight steel rebars in between the tile layers (Figure 11) (Espel and Faulí 2007).

The Guastavinos' work and writings were of great importance for the Madrilenian architect Luis Moya (1904-1990). The steel shortage after the Spanish Civil War and its bad quality forced the architects of that time to look for construction systems that 

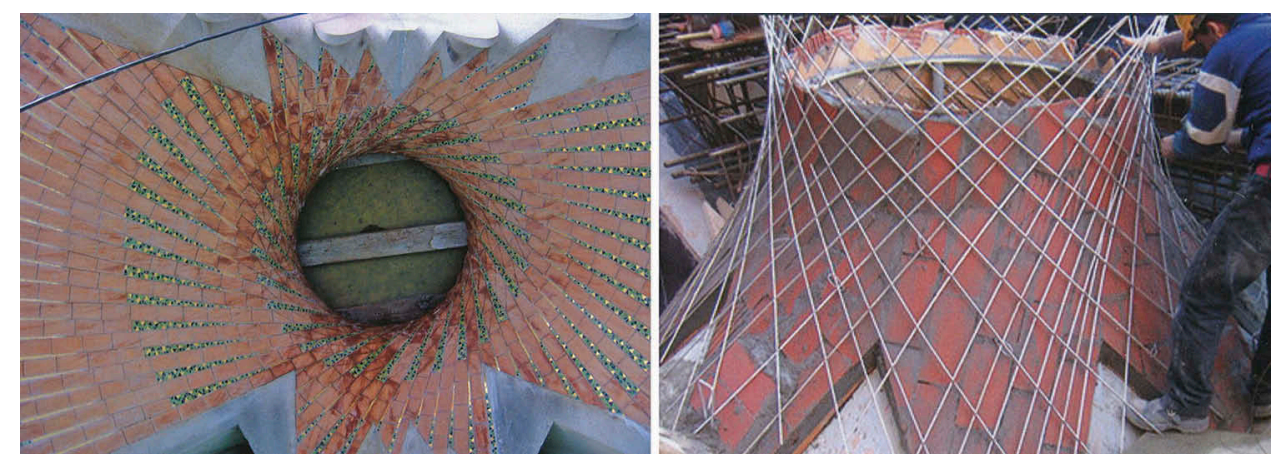

Figure 11. Reinforced tile vault at the Temple of Sagrada Familia in Barcelona. (Left) view of the intrados; (right) construction, placing of the reinforcement bars (Arxiu Temple Sagrada Familia).

would not require steel or would reduce it to the minimum (Moya 1947). The construction itself played a main role in Moya's architecture, having a direct link with architectural shape. These facts, his defense of the arts and crafts' revitalisation and the influence of the Guastavinos and Buenaventura Bassegoda, among others, led Luis Moya to the use of tile vaults in many of his extraordinary buildings (González 2004). Moya experimented, mainly in Madrid, with different features, shapes and configurations, such as series of contiguous tile vaults (avoiding the use of tension ties), their combination with crossed masonry arches (García-Gutiérrez 2001) and, in a later period, with steel reinforcement at the chapel of the School Santa María del Pilar (Moya and Domínguez 1965) (Figure 12, left). The chapel is covered with a $743.71 \mathrm{~m}^{2}, 14-\mathrm{cm}$-thick, reinforced tile vault. Its shape is a hyperbolic paraboloid and it was built using a falsework of wooden planks with a separation of $60 \mathrm{~cm}$. The vault has three layers of tiles and the reinforcement is placed in the $3-\mathrm{cm}$ thick joint between the first and the second layers (Figure 12, right) (Moya and Domínguez 1965). The roof is finished with a $10-\mathrm{cm}$ top layer of unreinforced light concrete and asphalt sheets (Moya 1963).

According to González (2004), Ángel Truñó (1895-1979) might have written his famous treatise about tile vaulting construction (Truñó ca.1951a, ca. 1951b), answering Moya's call for Catalan architects to "publish the long and detailed exposition that the Catalan tile vaults merit" (Moya 1947). In his treatise, Truñó includes an example of a reinforced tile vault. He describes the way to build a tension ring around a tile dome using steel reinforcement bars. In this case, the reinforcement is placed under the last finishing layer of bricks (Figure 13).

Nowadays, in the field of restoration, polymeric grids, glass-fiber meshes, basalt-fibre meshes, etc. are commonly used for the reinforcement of existing masonry structures, including tile vaults. Regarding its use in new constructions, it is also worth to mention the contribution by Michael Ramage and Matthew DeJong by applying a geogrid in between the layers of bricks (DeJong et al. 2011) to introduce tensile and bending capacity and to export the technique to seismic areas where these kind of constructions are normally
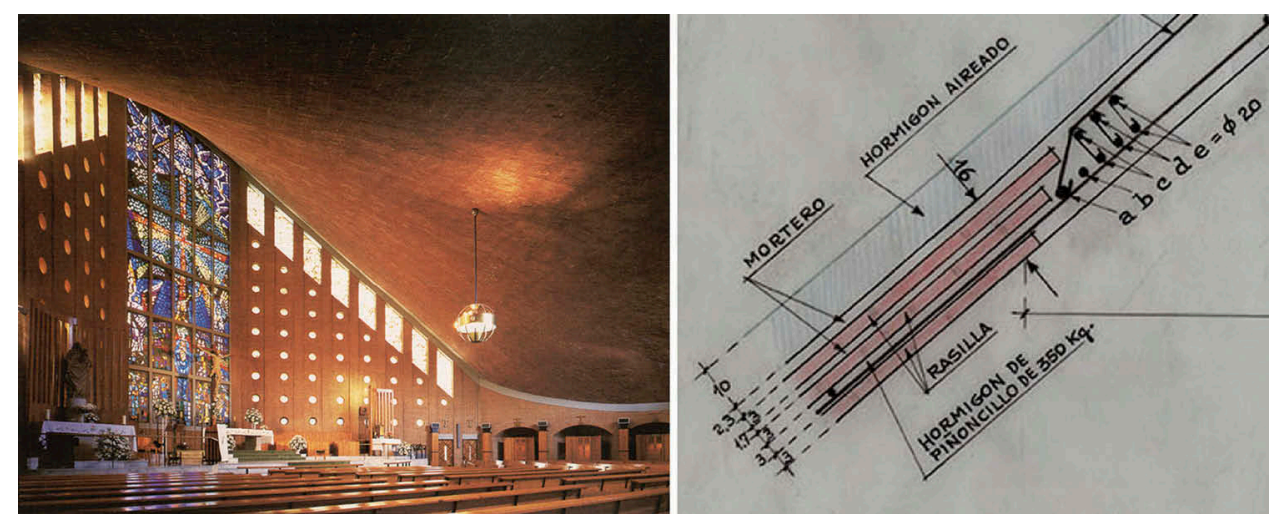

Figure 12. Chapel of the School Santa María del Pilar, Madrid. (Left) interior view (๔ E. Sánchez); (right) detail of the vault at the higher support (Fondo Luis Moya Blanco, Universidad Politécnica de Madrid). 


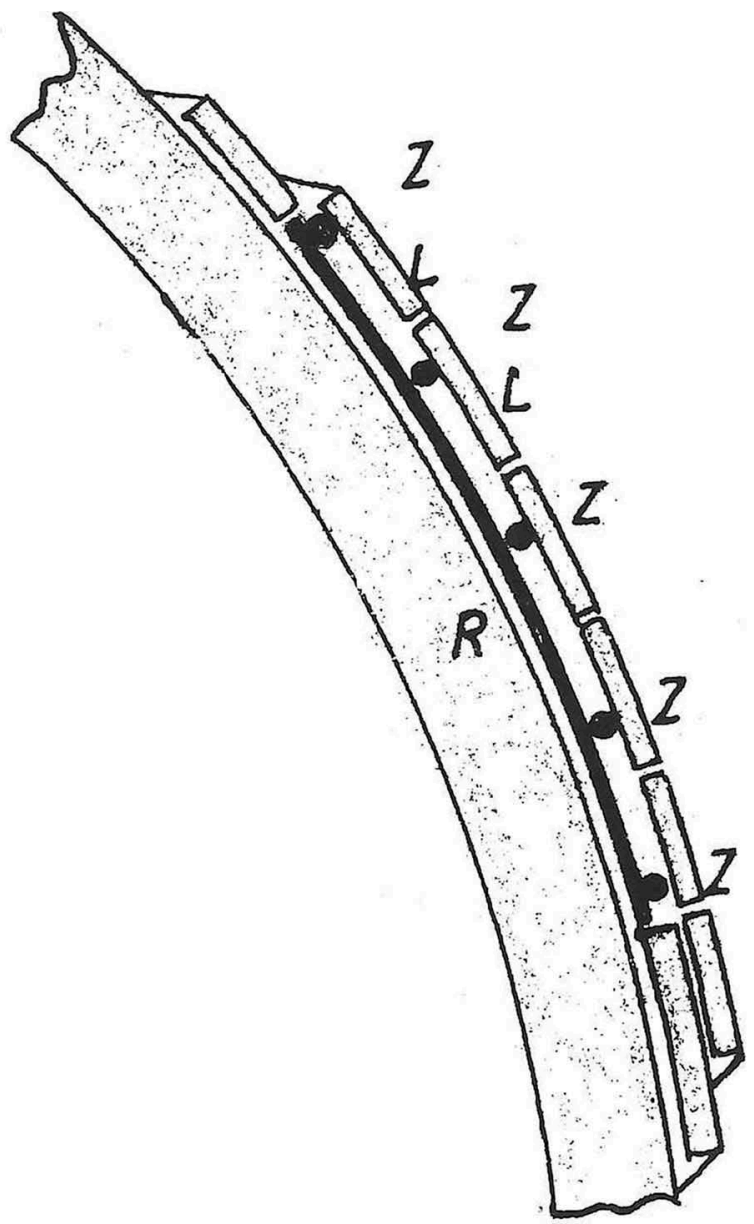

Figure 13. Tension tie made or steel reinforcement bars around a tile dome under a last finishing layer of bricks (Truñó ca. 1951b).

directly rejected. The system was tested in the Bowls Project in San Francisco and implemented in the Earth Pavilion in London, both in 2010 (Ramage and DeJong 2011). The geogrid was used in the Bowls Project for seismic reasons, whereas in the Earth Pavilion it was justified as a way to reduce the thickness of the vault and for stiffening reasons (Ramage, Hall, and Rich 2015).

\section{Structural analysis and design}

Guastavino Jr.'s knowledge of graphic statics allowed him to identify and estimate the possible tensile stresses in the vaults or domes (Huerta 2001). He would then use the required metallic reinforcement, tension ties or flying buttresses in those specific spotted places. Figure 14 shows one of Guastavino Jr.'s drawings of the St. John the Divine's Cathedral. A graphic analysis can be seen superimposed over the cross-section of the crossing dome (Figure 14, right), and metallic reinforcement can be observed in between the layers of the tile vault (Figure 14, left).

It is also worth highlighting that Guastavino Jr. used graphic statics not only as an assessment tool, but also as a form-finding method, optimizing the vault's and dome's shapes to eliminate tensile stresses and thus increasing the refinement of the company's designs (Ochsendorf 2010).

As a Gaudís fan (and friend), Joan Bergós was also familiar with graphical and equilibrium methods to assess tile vaults. However, although recognizing that Gaudí did not admit the intervention of elasticity in the calculation of tile arches and vaults (Bergós 1953), Bergós applied the elastic equations to analyze the reinforced and unreinforced tile vaults included in his comprehensive experimental research published in 1965. This research was both an attempt to justify the application of the elastic theory and to obtain the required tile vault's elastic material properties (Huerta 2001).
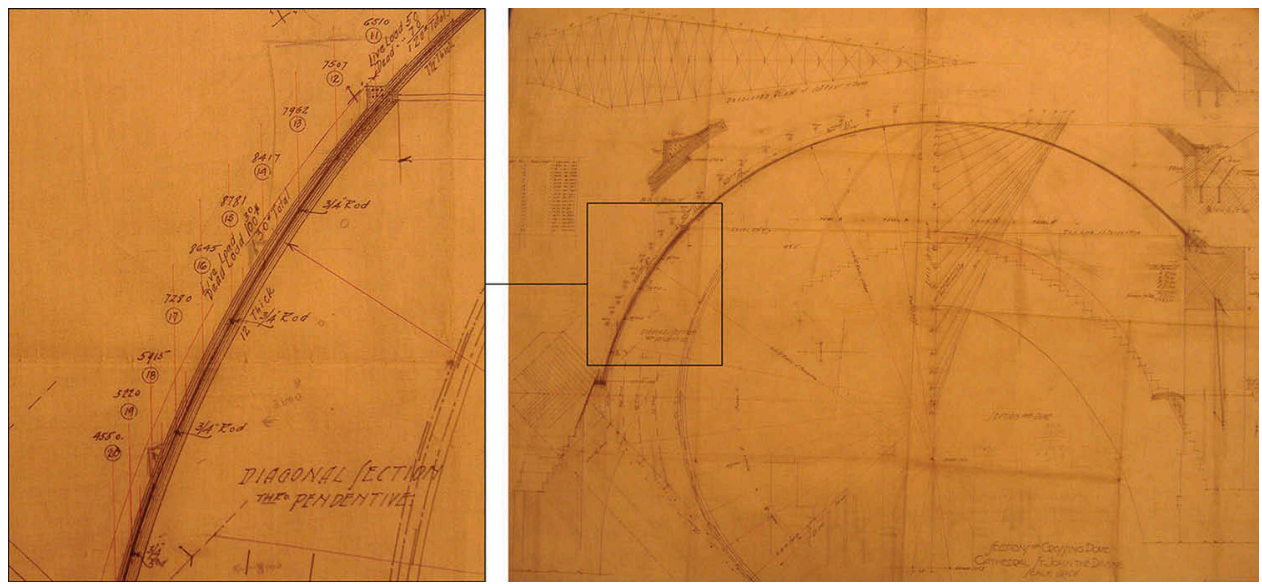

Figure 14. Section and graphical structural analysis of the crossing dome of St. John the Divine's Cathedral. (Left) detail of the reinforced tile vault; (right) general view of the drawing (Guastavino Archive, Avery Library). 
Luis Moya admitted in 1947 that there were no elastic coefficients that permitted the calculation of tile vaults yet and that their structural analysis could only provide an approximate idea of the masonry's maximum stresses: "Experience, and sometimes intuition, should complete what is missing" (Moya 1947). He then used graphical equilibrium methods to design tile vaults considering the predominant loads, and built the traditional stiffeners to resist punctual and/or asymmetric loads that may deviate the thrust line out of the vault's thickness. The more complex calculations of the hyperbolic, reinforced tile vault at the chapel of the School Santa María del Pilar in Madrid (1963-1965) were done by the architect Luis García Amorena (Moya and Domínguez 1965), who worked also with Moya on other projects, such as the chapel of the Universidad Laboral de Gijón in Spain.

Graphical methods are also enough to obtain the horizontal thrust and tensile stresses of Truñó's tile dome (Figure 13) and could have been his way to dimension the tension ring. The structural analysis of his examples was not included in his manuscript and was not the expertise of an architect who worked mainly as a builder and taught construction at the School of Architecture from 1948-1966. Considering simplicity and immediacy, simple graphical statics were likely Truñós chosen method to assess his tilevaulted structures.

Nowadays, computational tools have eased and sped up complex and tedious calculations. DeJong et al. (2011) used a finite element model for the modal analysis of geogrid reinforced tile vaults. They also calculated the bending capacity of the reinforced crosssection to obtain a "thrust envelope" defining the limits in which the thrust line should lie to achieve a stable structure (Ramage and DeJong 2011). The same approach was used four years before by Roca et al. (2007) for the Limit analysis of reinforced masonry vaults. Furthermore, starting from Roca et al. (2007), recent research by López López et al. (to be published) has developed, computationally implemented, and experimentally tested a method for the design and the structural analysis of two-dimensional structures made of reinforced masonry and/or concrete, including the specific case of tile vaults as formwork for reinforced concrete.

\section{Tile vault as formwork for reinforced concrete}

This system has the same above-mentioned advantages of tile vaults as formwork for unreinforced concrete structures (economy, efficiency, aesthetics, and reduction of waste) and offers new possibilities thanks to the reinforcement. The reinforcement allows a minimum thickness and makes the system feasible for long-span shells, which would probably be too massive and heavy otherwise. Furthermore, the addition of reinforcement, like in the case of reinforced tile vaults, allows the construction of expressive, free-form structures capable of resisting tensile stresses and bending moments, beyond the compression-only masonry restriction. As mentioned with regard to the previous systems, disadvantages include a higher weight compared to traditional tile vaults, a more complex structural behavior with the addition of the bonding between materials as a feature to consider and the need to provide sufficient concrete cover to prevent corrosion in the case of steel reinforcement.

The Guastavinos' research on new variants of tile vaults could not disregard this system. The U.S. patent by Guastavino Jr. from 1913 proposed a combination of a reinforced tile vault with reinforced concrete, having the reinforcement of both tile vault and concrete connected by a third metallic element (Guastavino Expósito 1913; Waite and Gioia 1999). Guastavino Jr. considered this patent as a continuation or an improvement of the one from 1910, mentioned in the previous section. He thought that this invention included "certain and practical improvements which carry forward the invention disclosed and covered in my [his] former Patent" (Guastavino Expósito 1913). The patent proposed the mentioned reinforced system indicating the possibility of different variants regarding the reinforcement, from which he illustrated his preferred ones (Figure 15).

The Spanish engineer Eduardo Torroja (1899-1961) was aware of the advantages of the tile vaulting technique. About tile vaults, he once wrote: “... tile vaults are an effective constructive invention because, with bricks and plaster or fast cement, a skilled mason can do in a few hours, a huge variety of resistant forms, without any other tool than drawer and palette" (Torroja 1957).

Torroja used the tile vaulting technique as formwork for reinforced concrete already in an early stage of his career. In 1926, he was working at Compañía de Construcciones Hidráulicas y Civiles, led by his former professor the engineer José Eugenio de Ribera. The company had the commission to build the Sancti Petri Bridge (Cádiz, Spain), and Eduardo Torroja designed the foundation scheme, which consisted of two reinforced, tile-vaulted, concentrical hyperboloids connected at their lower part forming a caisson that was a permanent formwork to be filled with concrete (Figure 16). The construction of these caissons was made with a single layer of hollow bricks and reinforcement connected with mortar cement facing the inside of the caisson (Torroja 1926, 1958). 

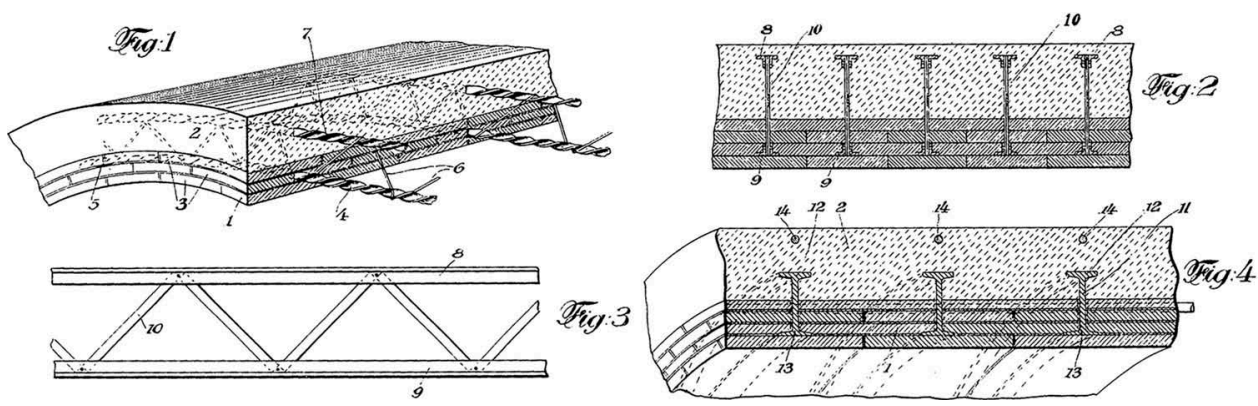

Figure 15. Guastavino Jr.'s drawings for his patent No. 1,052,142 (1913).
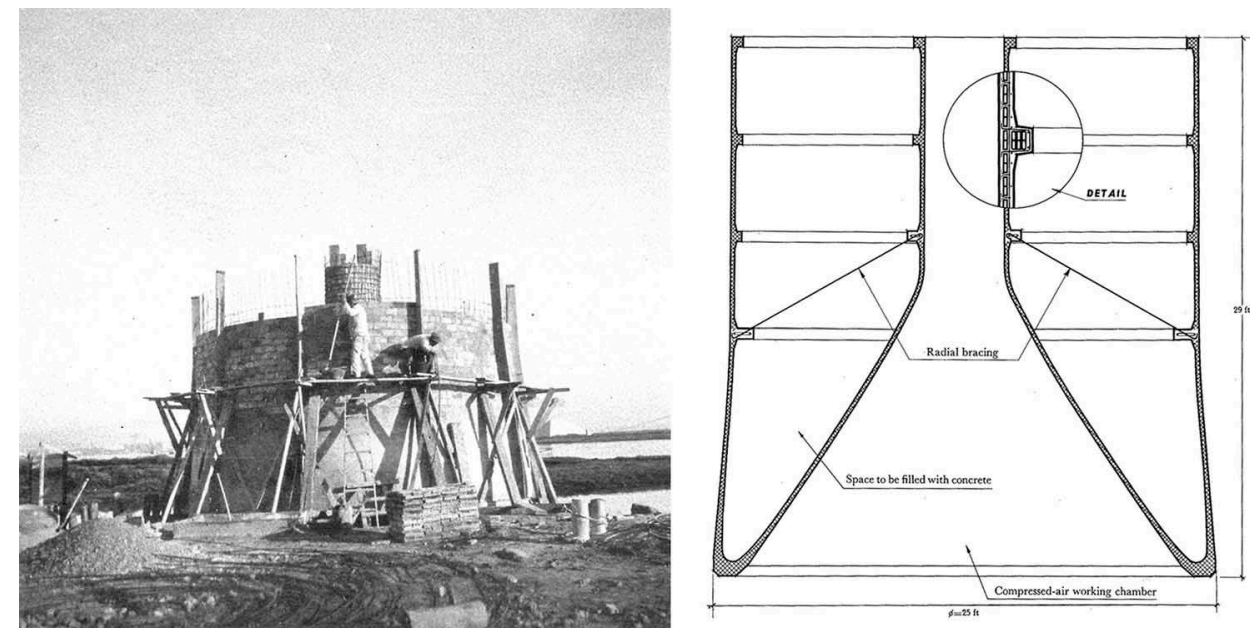

Figure 16. Foundations of the Sancti Petri Bridge (Cádiz, Spain). (Left) construction of a reinforced tile caisson (Eduardo Torroja Miret Archive, CEHOPU, ca. 1927); (right) detail of the caisson (Torroja 1958).

In 1952, Eduardo Torroja's design for the church in Pont de Suert at the Spanish Pyrenees included a construction system that is also worth to mention in this section (Figure 17). The construction scheme of the shells in the church is a tile vault with a top layer of reinforcement. However, according to Torroja (1962a), the reinforcement could have been placed also between the layers of bricks. The tile vaults are three-layered tile vaults made of hollow bricks (Torroja 1958, 1962a). The proportions of the materials' thickness (vault and reinforcement layer) in the Figure 17 (right) show the tile vault as the main structural element and the layer of cement mortar with reinforcement as the element to resist eventual tension or bending stresses. However, the scheme of building the tile vault first and then use it as formwork to place the reinforcement and the fact that the reinforcement is not embedded in between the tile layers, bring it closer to the concept of this section. This construction system was also planned for the chapel of the Ascensión at Xerrallo (1952), but the
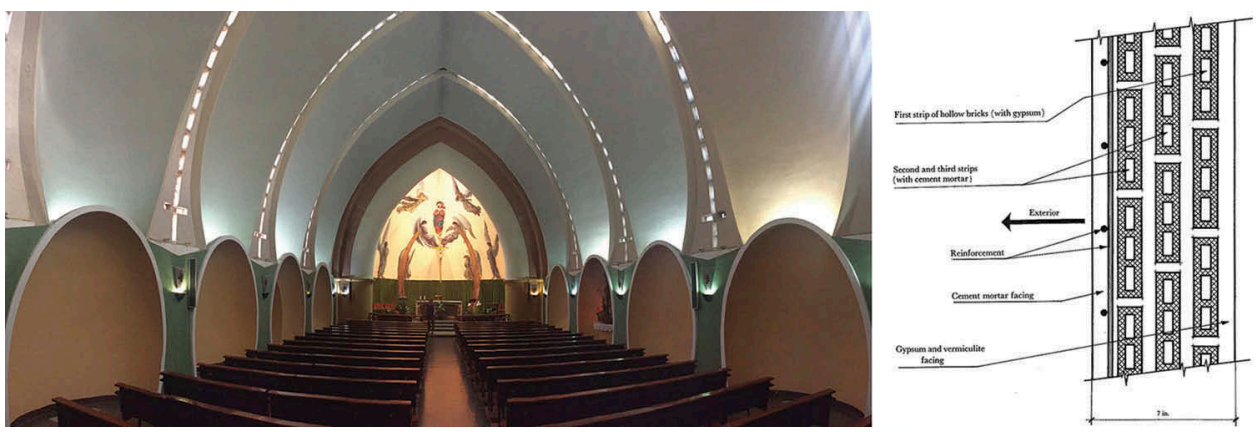

Figure 17. Church in Pont de Suert, Spain. (Left) interior view; (right) cross-section detail (Torroja 1958). 
available space forced a reconsideration of the entire design (Torroja 1958, 1962c). Nevertheless, he would use the system the next year, in 1953, for the small chapel Sancti Spirit, also in the Catalan Pyrenees (Figure 18) (Torroja 1958, 1962b).

Some years later, Torroja again used tile vaults, but this time unreinforced. He designed a three-layered tile vault for the coverage of a water tank in Fedala in 1956 (Fernández and Navarro 1999; Torroja 1962d) and for another water tank in 1957 that was not built (Torroja 1958).

Some of the few tile vaults built nowadays for floors, roofs, or stairs in new constructions incorporate a last layer of reinforced concrete, even for short-span, compression-only structures. This is in most cases not a structural requirement or a decision to reduce material or time, but a lack of knowledge on the structural analysis of masonry structures or a way for architects and engineers to feel confident about the stability of a kind of structures that are generally not included in the codes.

\section{Structural analysis and design}

Although Guastavino Jr. did not publish anything about the structural analysis of his specific system, the way he understood the composite structure made of tile vault and reinforced concrete is reflected in the text of his patent from 1913 (Figure 15) (Guastavino Expósito 1913). He claimed that his invention was "particularly

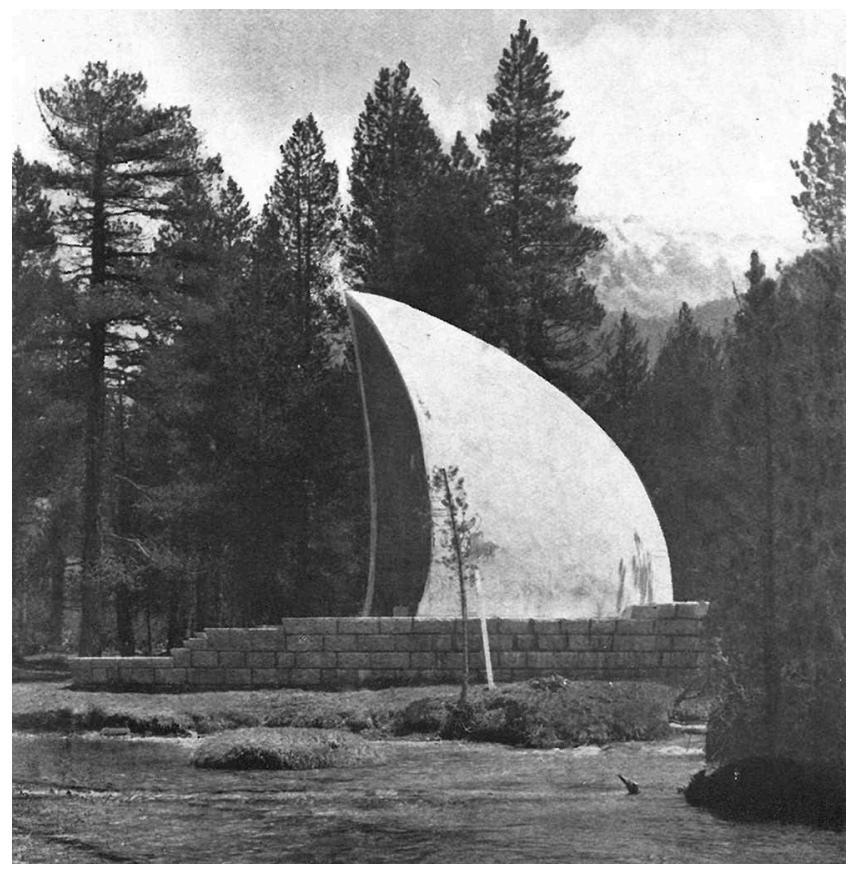

Figure 18. Chapel Sancti Spirit, Spain (Torroja 1962b). available for arch work in the building of bridges or long spans" and that it could resist great strength with a comparative thinness. According to Guastavino Jr., the system is a composite monolithic masonry arch. The reinforcement in the tile vault and the concrete would work in compression under normal conditions. It is only under heavy (live) loads, when the arch deforms, that the upper or the lower reinforcement (depending on the direction of the deformation) would work in tension and the connecting ties between the two levels of reinforcement take up the shearing stresses (Guastavino Expósito 1913). Therefore, and taking into account what is known about Guastavino Jr.'s skills with graphic statics, it is this graphical method what he could have used to design and analyse this kind of structures, taking the tile vault and the concrete as one "monolithic" material and calculating the tensile forces caused by heavy live loads to dimension the steel reinforcement accordingly.

Guastavino Jr. and Eduardo Torroja's architecture present clear differences, and so does their way to calculate their structures. However, they had something in common: their trust in the intuition acquired by years of experience in construction and structural design. According to Javier Manterola (Manterola 2011, quotation extracted from Luis Peñalver's Ph.D. dissertation), in a conversation between Eduardo Torroja and Ildefonso Sánchez del Río, the latter asked:

- How did you calculate the "Frontón Recoletos"?

- Look, Ildefonso, after 3 months with mathematicians, engineers and physicians and a lot of differential equations, a lot of unknowns..., at the end, Ildefonso, to tell you the truth, I did it more or less using a rule of thumb.

About the chapel Sancti Spirit (Figure 18), Torroja wrote that there was not a practical calculation method at that time to determine the stress state of a shell with such shape (Torroja 1962b). He relied on the modern laboratory techniques for the experimental analysis of stress states in laminar structures. He then concluded that in order to design these shells "only a certain intuitive knowledge of the stress phenomenon is needed, with the aim of choosing appropriate shapes that can afterwards be checked analytically or experimentally" (Torroja 1962b).

Intuition and experimental analysis were not his only tools though. For the structural assessment of the nave in Pont de Suert's church (Figure 17), he carried out an elastic analysis on the repeated geometrical element (the lobe). He considered an isotropic, homogeneous, and perfectly elastic material and, as boundary 


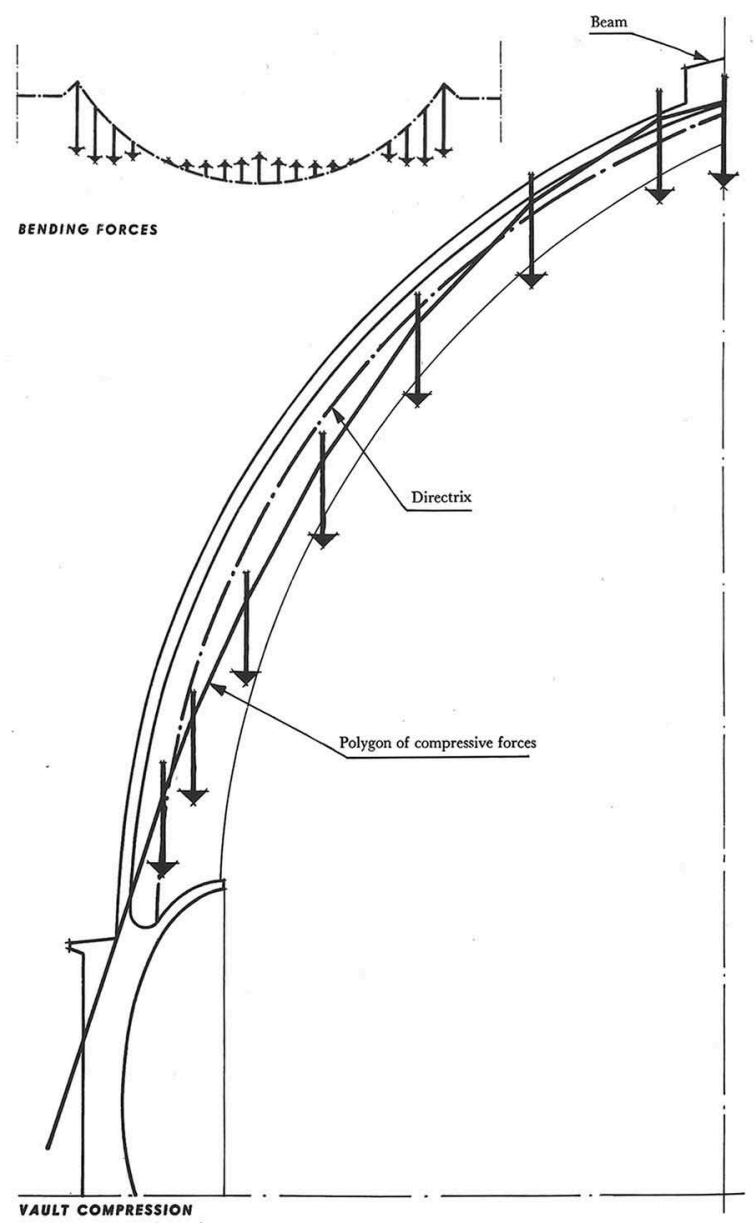

Figure 19. Graphic structural analysis of one lobe of the church in Pont de Suert, Spain. (Top) Bending moments at a strip of the shell in plan; (bottom) cross-section with the arch's internal line of compression (Torroja 1958).

conditions, the lower support fixed and a hinge at the crown (Ochsendorf and Antuña 2003). A longitudinal reinforced concrete beam along the nave links the lobes at their upper part and provides weight at the crown of the pointed arch that results as the cross-section of two opposed lobes. Torroja did a graphical calculation to illustrate the influence of this load on the stability of the structure (Figure 19, down). This wisely positioned weight approximated the arch's internal line of compression to its directrix. However, there were some deviations producing local bending, which was resisted thanks to the shell's reinforcement (Figure 19, up) (Torroja 1958).

\section{Conclusions}

Some of the inherent advantages of the tile vaulting technique (economy, efficiency, and expressiveness) can be enhanced by combining it with reinforcement and/or concrete. Using tile vaults as permanent formwork for concrete reduces time and labor, and therefore costs. The addition of reinforcement can reduce thickness, and therefore weight, material and costs. Furthermore, it allows the construction in seismic areas and permits building forms beyond the realm of compression only.

Tile vaulting combined with concrete and/or reinforcement has been used successfully by some of the architects with vast experience in tile vaulting, such as the Guastavinos, Gaudí, or Moya, and by other architects or engineers who were able to envisage the virtues and advantages of the traditional technique, such as Le Corbusier or Torroja. Given the success of these architects and engineers, the series of recent projects that have investigated novel applications and design possibilities for tile vaults and the growing interest in this technique (López López, Van Mele, and Block 2016b), its combination with reinforcement and/or concrete eliminates some of the traditional restrictions, opening again a new horizon to build (even) more economic, efficient, and expressive structures.

Many unknowns have always surrounded the structural analysis of these composite structures. The appropriate method to use for that purpose has been (and still is) a matter of controversy. A common position among architects and engineers in practice has been the efforts to simplify calculations and the trust in intuition based on experience. Current research has a gap to fill by providing simple and intuitive tools to analyse and design the kind of structures described in this article.

\section{Funding}

This work was supported by the Swiss National Science Foundation [P1EZP2_165203].

\section{ORCID}

David López López (D) http://orcid.org/0000-0002-3544-618X

\section{References}

Aguado, M. L., A. Ribas, and C. Hosta. 2002. La restauración de los pabellones de entrada del Park Güell. Informes De La Construcción 54(481-482):19-28.

Bergós, J. 1953. Materiales y elementos de construcción: Estudio experimental. Barcelona: Bosch.

Bergós, J. 1965. Tabicados huecos. Barcelona: Colølegi d'Arquitectes de Catalunya i Balears.

Buxadé, C., and J. Margarit. 2001. El hormigón en la Arquitectura: Aplicación a la construcción de la Sagrada Familia. Cemento Hormigón 826:730-40.

Cardellach, F. 1910. Filosofía de las Estructuras. Barcelona: Librería de Agustín Bosch.

Choisy, A. 1873. L'art de batir chez les Romains. Bologna: Forni Ed. 1969. 
Choisy, A. 1899. Histoire de l'architecture, Tome Premier. Paris: Vincent, Fréal \& C $C^{\text {ie }}$. Ed. 1955.

DeJong, M. J., M. H. Ramage, B. Travers, and S. Terry. 2011. Testing and Analysis of Geogrid-reinforced Thin-shell Masonry. Paper presented at the IABSE-IASS Symposium, London.

Espel, R., and J. Faulí. 2007. The construction of the project. In Gaudí Unseen. Completing the Sagrada Família, 140-51. Berlin: Jovis Verlag.

Espel, R., J. Gómez, R. Grima, and A. Aguado. 2009. La evolución de la construcción del Templo de la Sagrada Familia. Informes De La Construcción 61(516):5-20. doi:10.3989/ic.2009.v61.i516.

Fernández, J. A., and J. R. Navarro. 1999. Eduardo Torroja Miret, ingeniero, engineer. Madrid: Ediciones Pronaos SA.

Fortea, M. 2009. Origen de la bóveda tabicada. Paper presented at the Sexto Congreso Nacional de Historia de la Construcción, Valencia. Madrid: Instituto Juan de Herrera.

García, J., M. González, and J. C. Losada. 2012. Arquitectura y construcción tabicada en torno a Eduardo Sacriste. Informes De La Construcción 64(525):35-50. doi:10.3989/ic.09.065.

García-Gutiérrez, J. 2001. En paralelo a Guastavino, las bóvedas tabicadas en Madrid. In Las bóvedas de Guastavino en América, 47-57. Madrid: Instituto Juan de Herrera.

Gómez, J. 2001. El hormigón de alta resistencia en el Templo de la Sagrada Familia de Barcelona. Cemento Hormigón 826:717-29.

González, J. L. 2000. Configuración constructiva de las bóvedas "convexas" de la iglesia de la Colonia Güell, obra de Antonio Gaudí. In Paper presented at the Tercer Congreso Nacional de Historia de la Construcción, Madrid: Instituto Juan de Herrera.

González, J. L. 2004. La bóveda tabicada: Pasado y futuro de un elemento de gran valor patrimonial. In Prologue of Truñó, A. Construcción de bóvedas tabicadas, 11-60. Madrid: Instituto Juan de Herrera.

González, J. L., and A. Casals. 2002. Gaudí y la razón constructiva. Un legado inagotable. Madrid: Ediciones Akal.

Guastavino Expósito, R. 1892. Construction of Buildings. US Patent 468,871 .

Guastavino Expósito, R. 1910. Masonry Structure. US Patent $947,177$.

Guastavino Expósito, R. 1913. Masonry Structure. US Patent $1,052,142$.

Guastavino Moreno, R. 1891. Construction of Buildings. US Patent 464,562.

Guastavino Moreno, R. 1893. Essay on the theory and history of Cohesive Construction, applied especially to the timbrel vault. In Escritos sobre la construcción cohesiva y su función en la arquitectura, ed. S. Huerta, 1-96. Madrid: Instituto Juan de Herrera. 2006.

Gulli, R. 2001. La huella de la construcción tabicada en la arquitectura de Le Corbusier. In Las bóvedas de Guastavino en América, 73-86. Madrid: Instituto Juan de Herrera.

Huerta, S. 2001. La mecánica de las bóvedas tabicadas en su contexto histórico: La aportación de los Guastavino. In Las bóvedas de Guastavino en América, 87-112. Madrid: Instituto Juan de Herrera.
Huerta, S. 2006a. Structural Design in the Work of Gaudí. Architectural Science Review 49(4):324-39. doi:10.3763/ asre.2006.4943.

Huerta, S. 2006b. Prólogo. In Escritos sobre la construcción cohesiva y su función en la arquitectura, Madrid: Instituto Juan de Herrera.

López López, D., M. Domènech, and M. Palumbo. 2014. "Brick-topia", the thin-tile vaulted pavilion. Case Studies in Structural Engineering 2:33-40. doi:10.1016/j. csse.2014.09.001.

López López, D., T. Van Mele, and P. Block. 2016a. Dieste, González Zuleta and Sánchez del Río: Three approaches to reinforced-brick shell structures. In Paper presented at the 10th International Conference on Structural Analysis of Historical Constructions, London: Taylor \& Francis Group.

López López, D., T. Van Mele, and P. Block. 2016b. Tile vaulting in the 21st century. Informes De La Construcción 68(544):e162. doi:10.3989/ic.15.169.m15.

Lorenzo de San Nicolás, Fray. 1633. Arte y Uso de Arquitectura. Madrid.

Maniaque, C. 2005. Le Corbusier et les maisons Jaoul. Projets et fabrique. Paris: A. \& J. Picard.

Manterola, J. 2011. Ildefonso Sánchez del Río Pisón, Ingeniero. In Ildefonso Sánchez del Río, el ingenio de un legado, ed.. P. Cassinello, and B. Revuelta. Madrid, Fundación Juanelo Turriano.

Marín, A. M., and A. Trallero. 2005. El nacimiento de la cerámica armada. Paper presented at the Cuarto Congreso Nacional de Historia de la Construcción, Cádiz.

Martínez Fernández, R. 2011. Sistemas económicos de techado con bóvedas de fábrica: Bóveda nubia y bóveda recargada mexicana. In Paper presented at Construcción con tierra. Tecnología y Arquitectura. Congresos de arquitectura de tierra en Cuenca de Campos 2010/2011, 89-100. Valladolid: Universidad de Valladolid.

Moya, L. 1947. Bóvedas tabicadas. Madrid: Ministerio de la Gobernación, Dirección General de Arquitectura, Servicio de Publicaciones.

Moya, L. 1963. Memoria descriptiva de construcción y material y mediciones del proyecto para la construcción de una capilla y cripta en el colegio Santa María del Pilar. Fondo Luis Moya Blanco. Colección Digital Politécnica. (cdp. upm.es). Universidad Politécnica de Madrid.

Moya, L., and J. A. Domínguez. 1965. Capilla del colegio de Santa María del Pilar. Informes De La Construcción 173:49-61. doi:10.3989/ic.1965.v18.i173.4340.

Ochsendorf, J. 2010. Guastavino Vaulting. The art of structural tile. New York: Princeton Architectural Press.

Ochsendorf, J., and J. Antuña. 2003. Eduardo Torroja and "Cerámica Armada". In Paper presented at the first international congress on construction history, Madrid: Instituto Juan de Herrera.

Ramage, M. H., and M. J. DeJong. 2011. Design and construction of geogrid-reinforced thin-shell masonry. Paper presented at the IABSE-IASS Symposium, London.

Ramage, M. H., T. Hall, and P. Rich. 2015. Light earth designs: Natural material, natural structure. In Earthen architecture: Past, present and future, 305-10. London: Taylor \& Francis Group. 
Roca, P., F. López-Almansa, J. Miquel, and A. Hanganu. 2007. Limit analysis of reinforced masonry vaults. Engineering Structures 29:431-39. doi:10.1016/j. engstruct.2006.05.009.

Rodríguez, J. L. 2008. Memorias de los años 50. Conversación con Francisco Pizano. Dearquitectura 3:16-29.

Sacriste, E., P. A. Kechichian, and G. Mackintosh. 1977. Viviendas con bóvedas. Buenos Aires: Espacio Editora.

Tomlow, J. 2001. La bóveda tabicada a la catalana y el nacimiento de la 'cerámica armada' en Uruguay. In Las bóvedas de Guastavino en América, 241-51. Madrid: Instituto Juan de Herrera.

Torroja, E. 1926. Memoria. No 19.301. Archivo Eduardo Torroja Miret. ETM-018/Caja 005/02. Madrid: Centro de Estudios Históricos de Obras Públicas y Urbanismo.

Torroja, E. 1957. Razón y ser de los tipos estructurales. Madrid: Artes Gráficas MAG, SL.

Torroja, E. 1958. The structures of Eduardo Torroja. An autobiography of engineering accomplishment. Madrid: Centro de Estudios Históricos de Obras Públicas y Urbanismo (CEHOPU). 2000.

Torroja, E. 1962a. Iglesia de Pont de Suert. Informes De La Construcción 14(137):148-73.
Torroja, E. 1962b. Sancti spirit. Informes De La Construcción 14(137):148-74.

Torroja, E. 1962c. Capilla de la Ascensión. Informes De La Construcción 14(137):148-75. doi:10.3989/ic.1962.v14. i137.4935.

Torroja, E. 1962d. La Cuba Hiperbólica de Fedala. Informes De La Construcción 14(137):581-18. doi:10.3989/ic.1962. v14.i137.4937.

Truñó, A. ca. 1951a. Construcción de Bóvedas Tabicadas. Barcelona: Manuscript at the Library of the Colølegi d'Arquitectes de Catalunya.

Truñó, A. ca. 1951b. Construcción de bóvedas tabicadas. In ed.. S. Huerta, and J. L. González, Madrid: Instituto Juan de Herrera. 2004.

Waite, D., and P. Gioia. 1999. United States Patents Held by the Rafael Guastavinos, Father and Son. Preserving Historic Guastavino Tile Ceilings, Domes and Vaults, APT Bulletin 30(4):59-156.

Wendland, D. 2007. Traditional vault construction without formwork: Masonry pattern and vault shape in the historical technical literature and in experimental studies. International Journal of Architectural Heritage 1(4):311-65. doi:10.1080/ 15583050701373803. 